\begin{tabular}{|c|c|c|c|}
\hline & $\begin{array}{c}\text { International Journal of Current Research in } \\
\text { Biosciences and Plant Biology }\end{array}$ \\
\hline EXCELLENT \\
PUBLISHERS
\end{tabular}

\title{
Seed Invigouration Techniques - Important Tool for Sustainable Agriculture - A Review
}

\author{
Geetika Singh $^{1 *}$, Richa $^{2}$ and M.L. Sharma ${ }^{3}$ \\ ${ }^{1}$ Assistant Professor, MCM DAV College for Women, Sector-36 A, Chandigarh - 160 036, India \\ ${ }^{2}$ Professor, Department of Botany, Panjab University, Sector 14, Chandigarh - 160 014, India \\ ${ }^{3}$ Professor Emeritus, Department of Botany, Panjab University, Sector 14, Chandigarh - 160 014, India
}

*Corresponding author.

\begin{tabular}{|c|c|}
\hline Abstract & Article Info \\
\hline \multirow{9}{*}{$\begin{array}{l}\text { Seed treatment refers to the application of certain agents physical, chemical or biological } \\
\text { to the seed prior to sowing in order to suppress, control or repel pathogens, insects and } \\
\text { other pests that attack seeds, seedlings or plants and it ranges from a basic dressing to } \\
\text { coating and pelleting. Losses in seed quality occur during field weathering, harvesting and } \\
\text { storage. Rapid deterioration occurs due to these environmental conditions make very } \\
\text { difficult to maintain its viability during storage. Invigouration treatments that include both } \\
\text { presowing and pre storage treatments. Pre sowing that includes Infusion, Fortification and } \\
\text { Osmopriming with various bioactive chemicals, are known to improve the seed } \\
\text { performance. Pre storage includes Pelleting and hardening proved to be very effective for } \\
\text { seed vigour. Lack of awareness to seed treatments at farmer's level is one of the limiting } \\
\text { factors in its management and therefore efforts should be made at farmer's level to contain } \\
\text { the technology. Keeping the all above facts in mind, selected seed treatment technologies } \\
\text { with their improvement and significance will be discussed in this review. }\end{array}$} & $\begin{array}{l}\text { Accepted: 02 January } 2017 \\
\text { Available Online: 06 January } 2017\end{array}$ \\
\hline & Keywords \\
\hline & Fort \\
\hline & Hardening \\
\hline & Infusion \\
\hline & Osmopriming \\
\hline & Pelleting \\
\hline & \\
\hline & \\
\hline
\end{tabular}

\section{Introduction}

Seed invigouration is ascribed to beneficial treatments applied to seeds that improves germination. Many seed invigouration treatments are being employed to improve seedling establishment under normal and stressful conditions. The treatments used to invigourate seeds include hydropriming; seed hardening; on farm priming; osmopriming; osmohardening; humidification; matripriming; priming with plant growth regulators, polyamines, osmolytes; coating technologies, and more recently pre sowing dry heat treatments . Induction of hydrolases such as amylases, lipases, proteases and antioxidants are reported to be the basis of improved performance using these techniques. Despite certain limitations, such as water potential, temperature and oxygen, seed invigouration studies have been worthwhile. Seed invigouration treatments are physiological in nature and classified into two types- pre sowing treatments for improved field performance and pre storage treatments for better storability. Seed fortification, infusion and osmopriming are the important pre-sowing treatments and pelleting, hardening are pre-storage treatments to accomplish seed 
vigour and increase the yield and quality of seeds. Considering these limitations with a growing world population, there has been a growing interest to develop such management practices/tools which alone or in combination with other practices could bring about a reasonably good degree of reduction of inoculum potential and at the same time ensure the sustainability of the production, cost effectiveness and healthy ecosystem and 'seed treatment' is one of these tools (Sanjeev Kumar, 2012). Seed treatment like baby care being with the mother (Heydecker and Coolbear, 1977) and it ranges from a basic dressing to coating and pelleting (Dubey, 2011).

\section{Invigouration techniques}

Seed invigoration techniques are value-added treatments applied on a given seed lot to improve its field performance. This term is often used interchangeably with seed priming. However, it is an umbrella term, which comprises many pre-sowing and pre storage techniques. Seed invigoration or seed enhancements are "post-harvest treatments to improve germination and seedling growth or to facilitate the delivery of seeds and other materials required at the time of sowing or before sowing. Seed invigouration techniques are the most important developments to help rapid, uniform germination, emergence of seeds and to increase seed tolerance to adverse environmental conditions to maintain viability for longer periods. Less expensive and easily practicable invigouration methods like hydration and dehydration treatments (Basu, 1976) and short term aerated hydration (Thorton and Powell, 1992) to improve vigour, viability and field performance have been reported. It is an improvement in seed performance by any post harvest treatment result in improved germinability, greater storability and better field performance than the untreated control.

\section{Pelleting}

Pelleting is defined as the deposition of a layer of inert materials that obscures the original shape and size of the seed resulting in a substantial weight increase and improved plant ability (Taylor et al., 1995). This method is used to protect rhizobia, increase in seed size (Halmer,
2004), attract moisture, stimulate germination and supply oxygen. The main object of seed pelleting is precision, especially in very small seeds, with added advantage of increased productivity. There are three basic steps involved in pelleting are stamping, coating and rolling. Materials needed for pelleting are seed, adhesive and filler material. Seed pelleting was found to increase the germination and better seed establishment and seed yield in green gram (Kavitha, 2002). Seed pelleting will be relevant in direct sown irrigated crops which improve vigour for sustained crop growth and development to overcome adverse conditions.

\section{Hardening}

It is a method to overcome adverse conditions like low rainfall, inadequate soil moisture, soil fertility which prevent the germination. Seed hardening given as pre sowing treatment serve as a boon for dry land agriculture. Seeds of sorghum, pigeon pea, cow pea, groundnut soaked for $12,4,4,6 \mathrm{hrs}$ respectively in $\mathrm{CaCl}_{2}(0.4 \%)$ and cyclocel $(0.2 \%)$ registered maximum germination percentage, vigour index, root and shoot length (Rangaswamy et al., 1993). Seed hardening is the process of hydrating the seed to initiate the pre germinative metabolism followed by dehydration which fixes the biochemical events. For seed hardening, various chemicals such as $\mathrm{KCl}$, succinic acid, ascorbic acid; growth regulators like IAA, GA, NAA; plant nutrients; and animal and plant waste are used.

\section{Fortification}

It is process of enriching the seeds with bioactive chemicals for improving the germination and seedling vigour. This method involves the impregnation of required substance for invigourating seed for improved production. It is a process of enriching the seeds with bioactive chemicals for improving the germination and seedling vigour. This method involves an impregnation of required substances for invigourating the seed for improved production. Here the seeds are soaked either in water or dilute solutions of bioactive chemicals such as micronutrients, growth regulators, vitamins and seed protectants. Soaking duration of 6-24 hrs is required depending upon the crop. Moisture content of seeds is 
raised to 20-25\% just enough for endogenous impregnation of chemicals by endogenous application. The choice of chemicals, its concentration and duration of soaking vary with the species and decide the success of the treatment.

\section{Infusion}

This is a method of impregnation of seeds with bioactive chemicals through organic solvents instead of water. This infusion helps to avoid the damage caused to the seeds due to soaking in water and seed coat injury. Simultaneously, it also provides protective, regulatory and selective function of the chemicals to improve the performance of seeds with the help of organic solvent. Duration of treatment is 5-24 hrs depending upon the species. After the desired period, the solvent is evaporated by air or vacuum desiccators for 30mins to 1 hour. After complete evaporation, seeds are ready for sowing. The chemicals used for treatments are seed protectants, growth regulators, nutrients, herbicide, antidote, etc. The organic solvents used in technique include acetone, petroleum ether, ethanol dichloromethane and dichloroethane.

\section{Osmopriming}

It is the process of controlled hydration of seeds to a level that permits pre- germinative metabolic activity to proceed but prevents actual emergence of the radicle. Seeds are soaked in variety of solutes, including solutions of various inorganic salts, sugars and polyethylene glycol (PEG) a chemically inert, high molecular weight compound does not penetrate the cell walls. The duration of priming varies with the crop. They used different terms depending upon the methods adopted for priming (Heydecker et al., 1973), e.g. osmopriming: Soaking the seeds in osmotic solutions, halopriming: Soaking the seed in salt solutions, biopriming: Coating the seeds with biological agents like bacteria,solid matric priming: This consist of mixing seeds with an organic or inorganic carrier and water for a period of time. The moisture content of the matric is brought to a level just below what is required for radicle protrusion, seed water potential is regulated by the matric potential of the seed and during priming the water is largely held by the carrier. Seed can imbibe water from the carrier till the equilibrium is reached.

\section{Conclusion}

Invigouration techniques have been proved to be very effective in maintaining seed viability for longer duration .Future research may be more focused on advanced physical (microwave, ultrasound, ozone treatment) and biological (biopriming, SMP) methods of treating seeds alternative to chemical seed treatment. Seed treatment is an initial step in raising a crop and therefore plays a major role in maintaining sustainable agriculture. The high cost of GM seed is a key factor in the high demand for and growth of chemical seed treatments. With the regulatory issues facing both granular and fumigant nematicides, there has been a great deal of focus on seed treatment uses of nematicidal and nematistatic products. A critical success factor for the seed treatment market was the development of a complete protection solution against various plant stressors in a single product that is grower-friendly, crop-friendly and environmental friendly.

\section{Conflict of interest statement}

Authors declare that they have no conflict of interest.

\section{References}

Basu, R.N., 1976. Physico-chemical control of seed deterioration. Seed. Res. 4, 15-23.

Dubey, K., 2011. Insecticide and fungicide seed treatment. Retrieved: 1 September, 2014 from http:// agropedia.iitk.ac.in/content/insecticide-andfungicide seed-treatment.

Halmer, P., 2004. Methods to improve seed performance in the field. In: Handbook of Seed Physiology (Eds.: Benech-Arnold, R.L., Senchez, R.A.). New York, Food Products Press, The Harworth Press, Inc. pp.125-166.

Heydecker, W., Coolbear, P., 1977. Seed treatments for improved performance - survey and attempted prognosis. Seed Sci. Technol. 5, 353-425.

Heydecker, W., Higgins, J., Gulliver, R.L., 1973. Accelerated germination by osmotic seed treatment. 
Nature. 246, 42-44.

Kavitha, S., 2002. Seed hardening and pelleting for maximizing the productivity of blackgram (Vigna mungo L. Hepper). Cv. Vamban 3 under rainfed conditions. M.Sc. (Agri.) Thesis, Tamilnadu Agric. Univ., Coimbatore, India.

Rangaswamy, A., Purushotham, S., Denasenapathy, P., 1993. Seed hardening in relation to seedling quality characters of crop. Ind. J.Agri. Sci. 67(10), 678-680.
Sanjeev Kumar., 2012. Cultural approaches for plant disease management. Res. Rev. J. Agric. Sci. Technol. 1(2), 12-21.

Taylor, A.G., Lee, S.S., Beresniewicz, M.M., Paine, D.H., 1995. Amino acid leakage from aged vegetable seeds. Seed Sci. Technol. 23, 113-122.

Thorton, J.M., Powell, A.A., 1992. Short term aerated hydration for the improvement of seed quality in Brassica oleracea L. Seed Sci. Res. 2, 41-49.

\section{How to cite this article:}

Singh, G., Richa, Sharma, M. L., 2017. Seed invigouration techniques - Important tool for sustainable agriculture A review. Int. J. Curr. Res. Biosci. Plant Biol. 4(1), 119-122. doi: http://dx.doi.org/10.20546/ijcrbp.2017.401.015 